\title{
Possibilities of utilizing organic-poor metalliferous black shales (argillite)
}

\author{
Rein Palvadre*
}

\begin{abstract}
The present paper is focused on the possibilities of recovering rare metals molybdenum (Mo), uranium (U) and vanadium (V) from organic-poor metalliferous black shales on an example of Estonian argillite. For this purpose two flowsheets for processing argillite have been proposed: one is based on the separation of organic matter (OM) together with allied rare metals, and the other on the combustion of argillite in the presence of salts without prior separation of OM. For the recovery of rare metals from leaching solutions the anion exchange method was used. The influence of different parameters, such as metals concentrations and pH of leaching solutions, on the sorption process was studied.
\end{abstract}

Keywords: argillite, molybdenum, uranium, vanadium, anion exchange, leaching solution.

\section{Introduction}

In North Estonia Ordovician graptolitic argillites extend along the shore from west to east, forming a dark-brown layer of 1-7 m decreasing eastward. Argillites overlie shelly phosphorites and underlie glauconitic sandstones. The hypothetical geological reserves of argillite in Rakvere phosphorite field are estimated at $3 \times 10^{9} \mathrm{t}$, while those of Toolse amount to $141 \times 10^{6} \mathrm{t}[1,2]$. Argillites are characterised by an average organic matter (OM) content of $12-16 \%$ and a relatively high content of rare metals such as molybdenum (Mo), uranium (U) and vanadium (V). A comparative study of the contents of Mo, $\mathrm{U}$ and $\mathrm{V}$ in argillites from different deposits was carried out by Lippmaa et al. [3]. Due to their low organic content, argillites are not suitable for direct use as solid fuel or for production of oil. In addition, in the process of phosphorite mining they may represent a potential environmental hazard. During the opencast mining of phosphorite at Maardu quarry, North Estonia argillite was disposed of in dumps. The unused argillite caused the leaching of heavy metals into the natural water. In the dumps the oxidation and decomposition of pyrite took place, causing their self-ignition, which in turn promoted the leaching process. For that reason the Institute of Chemistry of Estonian Academy of Sciences, during the period 1960-1980, carried out complex research on the

\footnotetext{
* Corresponding author: e-mail rein111@hot.ee
} 
possibilities of utilizing argillite remained by phosphorite mining. A process of multistage leaching using fluidized-bed ashing and subsequent treatment of ash with cconcentrated sulphuric acid was developed by Maremäe et al. [4]. The percolation leaching method was investigated in terms of the possibilities of argillite processing for recovery of metals and reducing processing costs [5]. However, the disadvantages of the sulphuric acid leaching process are a high consumption of concentrated sulphuric acid and a large amount of acidic wastes generated. The method of water leaching of mildly preroasted argillite using chemical additives was suggested earlier, but there was a problem with organic matter utilization [3]. The present study aims to find other possibilities of utilizing low-grade black shales argillites. One option would be to separate organic matter and rare metals allied with it, thus significantly decreasing the amount of material to be processed, as well as reducing the costs of further processing [6]. An alternative would be the leaching of metals from ground argillite after its combustion by salt roasting, which enables using weaker reagents in the leaching process and thereby reducing the costs. The possibilities of applying the ion exchange method for the selective recovery of Mo, $\mathrm{U}$ and $\mathrm{V}$ by using model solutions were studied. On the basis of the data obtained, a scheme for the recovery of metals is presented.

\section{Experimental setup}

In this work, the results of neutron activation analysis of metal contents in argillite from the deposits of Maardu in North Estonia and Toolse in Northeast Estonia obtained earlier by Pelekis et al. [7, 8] were used. The samples under study were analysed for uranium content by using X-ray fluorescence spectroscopy, while atomic absorption spectroscopy was applied to determine the contents of molybdenum and vanadium. In the ion exchange process, titration was used for determination of the contents of $\mathrm{U}$ and $\mathrm{V}$, and colorimetry was employed to determine the Mo content. The results of metal content analysis show molybdenum, uranium and vanadium to be the most important metals in argillite, due to their relatively high concentrations, as well as good commercial potential, and significant environmental impact by phosphorite mining. Therefore the recovery of these metals from argillite is the primary focus of the current study.

\section{Correlations between rare metal contents in argillites}

The flowsheets for splitting argillites into different fractions with the aim to obtain organic matter and pyrite concentrates have been presented previously $[9,10]$. On the basis of the distribution of rare metals in the different fractions of argillites, the coefficients of linear correlation between the contents of 
metals and minerals were calculated and the correlation matrixes for Maardu and Toolse argillites were presented [11]. The data show a strong positive correlation to exist between the contents of Mo and $U$ and that of OM, the respective coefficients being 0.9 and 0.8 . At the same time, the content of $\mathrm{V}$ does not have such a good relationship with that of OM (the correlation coefficient for Toolse argillite is 0.7 ), while the correlation between the contents of $\mathrm{V}$ and illite is positive (the correlation coefficient is 0.51 ). The contents of all three rare metals are negatively correlated with that of pyrite, the respective correlation coefficients being $-0.46,-0.6$ and -0.59 , and of quartz, the correlation coeffcients are $-0.41,-0.32$ and -0.41 , respectively. It must be pointed out that Toolse and Maardu argillites differ significantly in mineral composition [12]. The content of pyrite in Toolse argillite is higher, and pyrite and quartz are mainly present as macrocrystals and concretions. In Maardu argillite fine-grained pyrite is strongly impregnated with quartz and clay minerals. Hence, in the beneficiation process, pyrite may be separated from Toolse argillite at relatively high recovery (about 80\%), while its recovery from Maardu argillite is not as high. However, unlike Maardu argillite, OM in Toolse argillite is more strongly associated with the mineral part, which requires a more thorough fine grinding for its complete disaggregation. These specificities must be taken into account during the recovery of OM-associated rare metals from argillites. The rare metal contents in Toolse argillite are many times these in Maardu argillite.

The association of rare metals with organic matter in black shales has been demonstrated by several authors. The strong correlation of the contents of Mo $(0.79)$ and V (0.71) with that of organic carbon in the Middle Cambrian aluma shale in Sweden has been reported by Armands [13]. Leventhal and Hosterman [14] show a good correlation to exist between the contents of organic carbon and uranium, as well as between those of organic carbon and molybdenum in U.S. Devonian black shales.

On the basis of the available data about the association of rare metals with OM, Palvadre and Ahelik [6] developed a flowsheet for argillite processing that involved the separation of OM.

\section{The recovery of rare metals into different fractions by the separation of organic matter from argillite}

Processes for beneficiation of Maardu and Toolse argillites relative to organic matter have been described earlier [6]. In this paper, a detailed flowsheet, which involves combined hydrocycling and flotation, for the process of separation of OM from Toolse argillite, with yields of fractions, is shown in Figure 1. The results of recovery of rare metals into different fractions of OM are presented in Table 1. The table reveals that in the hydrocycling processes, an approximately $70 \%$ recovery of rare metals into light fractions at the $55 \%$ 
product yield from the feed material was obtained. Light fractions of both hydrocycling processes were directed to the flotation process. As seen from Table 1, in the beneficiation process of Toolse argillite the recovery of rare metals into the froth products of flotation F-1-1 and F-2-2 was $72-75 \%$ at the product yield of approximately $50 \%$ from the feed material, while the recovery of $\mathrm{OM}$ in this case was $87.9 \%$. In the further cleaning flotation, the concentrations of rare metals increased, but their recovery into froth products and the product yield from the feed material decreased. For example, the total recovery of rare metals into cleaner flotation concentrates F-1-2 and F-2-2 was approximately $60-65 \%$ at the $40 \%$ product yield from the feed material, the OM recovery being $80 \%$. The rare metals recovery into total final concentrates $\mathrm{C}-1$ and F-2-2 was approximately $30 \%$ at the $15.5 \%$ product yield. Thus the process of flotation must be optimized for a compromise between metals recovery and product yield. The recovery of metals can be improved by directing the tailings back to the flotation process. The mineral tails from both flotation processes and the products of pyrite flotation were removed as wastes. The total yield of wastes from the processing of Toolse argillite was approximately $40 \%$ and the recovery of rare metals into wastes was $22-25 \%$ [6].

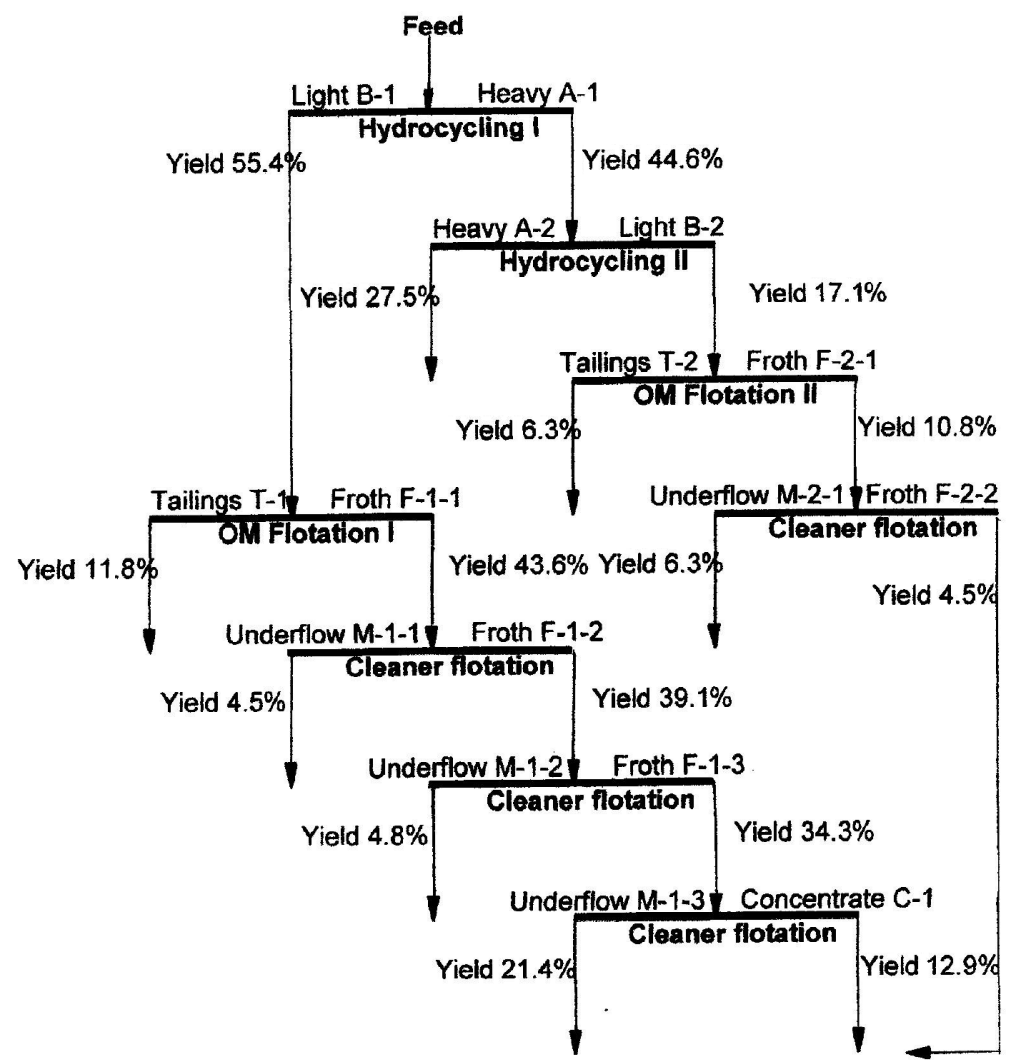

Fig. 1. A detailed flowsheet for the process of separation of organic matter from Toolse argillite, with yields of fractions. 


\begin{tabular}{|c|c|c|c|c|c|c|c|c|}
\hline & 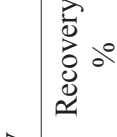 & $\stackrel{8}{8}$ & $\stackrel{\text { iे }}{i}$ & $\stackrel{+}{\circ} \underset{\infty}{\infty}$ & 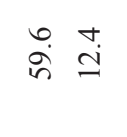 & 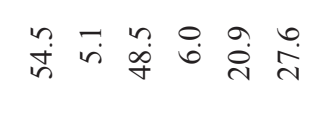 & $\stackrel{\leftrightarrow}{\perp} \dot{\infty}_{0}^{\infty}$ & $\ddot{n}=$ \\
\hline & 离茄 & $\stackrel{\circ}{=}$ & 兽 & $\stackrel{\mathscr{\varrho}}{\mathrm{a}}$ & $\stackrel{\circ}{\underline{n}}$ & 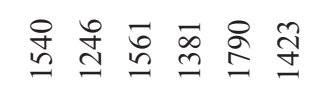 & 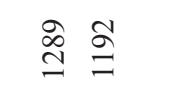 & 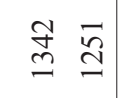 \\
\hline & 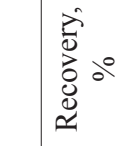 & $\stackrel{8}{\circ}$ & $\underset{n}{n} \underset{i}{n}$ & $\stackrel{\infty}{\infty} \underset{\infty}{\infty}$ & 范灾 & 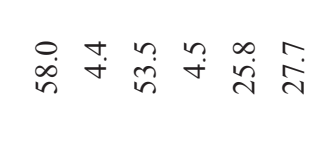 & $\begin{array}{l}m \\
g\end{array}$ & 38 \\
\hline & 俤吉 & $\stackrel{\square}{\square}$ & 굥 & $\hat{I} \vec{n}$ & $\widetilde{\Upsilon} 2$ & 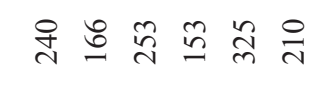 & 学昌 & సે $₫$ \\
\hline & 这 & $\ddot{\dot{\theta}}$ & :̊ & స્ત & $\dot{D}^{2}{ }^{\infty}$ & 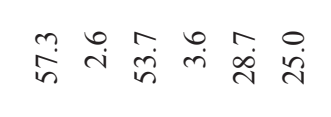 & $\overrightarrow{ \pm}$ & $\stackrel{1}{2}$ \\
\hline & 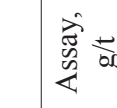 & $\tilde{8}$ & 哭确 & 8 & $\tilde{\Xi} \vec{\sigma}$ & 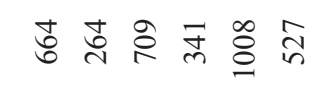 & పे & $\bar{c} \frac{\partial}{n}$ \\
\hline & 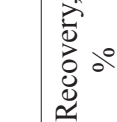 & $\ddot{\dot{\theta}}$ & के $\vec{i}$ & 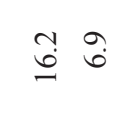 & $\vec{i} \underset{i}{i}$ & 엇 & $\stackrel{\infty}{\stackrel{j}{j}} \underset{i}{i}$ & 29 \\
\hline & 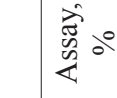 & $\stackrel{?}{=}$ & 守 & $\underset{\Theta}{\dot{\sigma}}+\dot{+}$ & ติ่ & ت̃ & $\vec{i} \dot{0}$ & 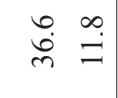 \\
\hline & $\frac{\pi}{0}$ & $\ddot{\dot{\theta}}$ & 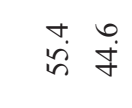 & $=\frac{n}{d}$ & $\stackrel{\circ}{\dot{\gamma}} \stackrel{\infty}{=}$ & 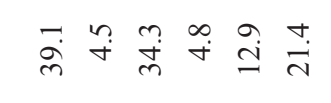 & $\stackrel{\infty}{\stackrel{0}{=}}$ & $\stackrel{2}{7} 3$ \\
\hline & 总 & \multicolumn{7}{|c|}{ 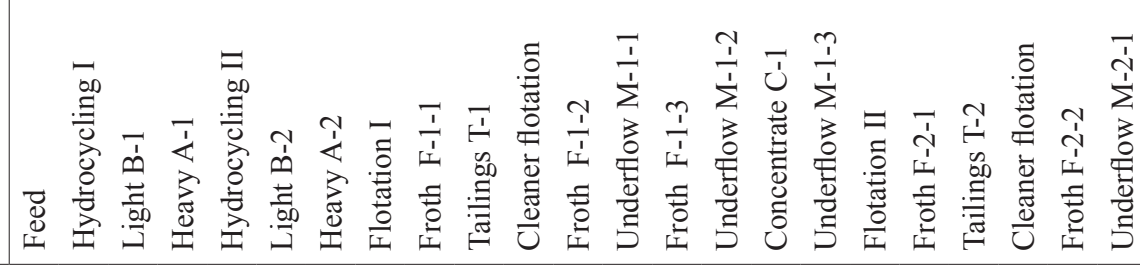 } \\
\hline
\end{tabular}




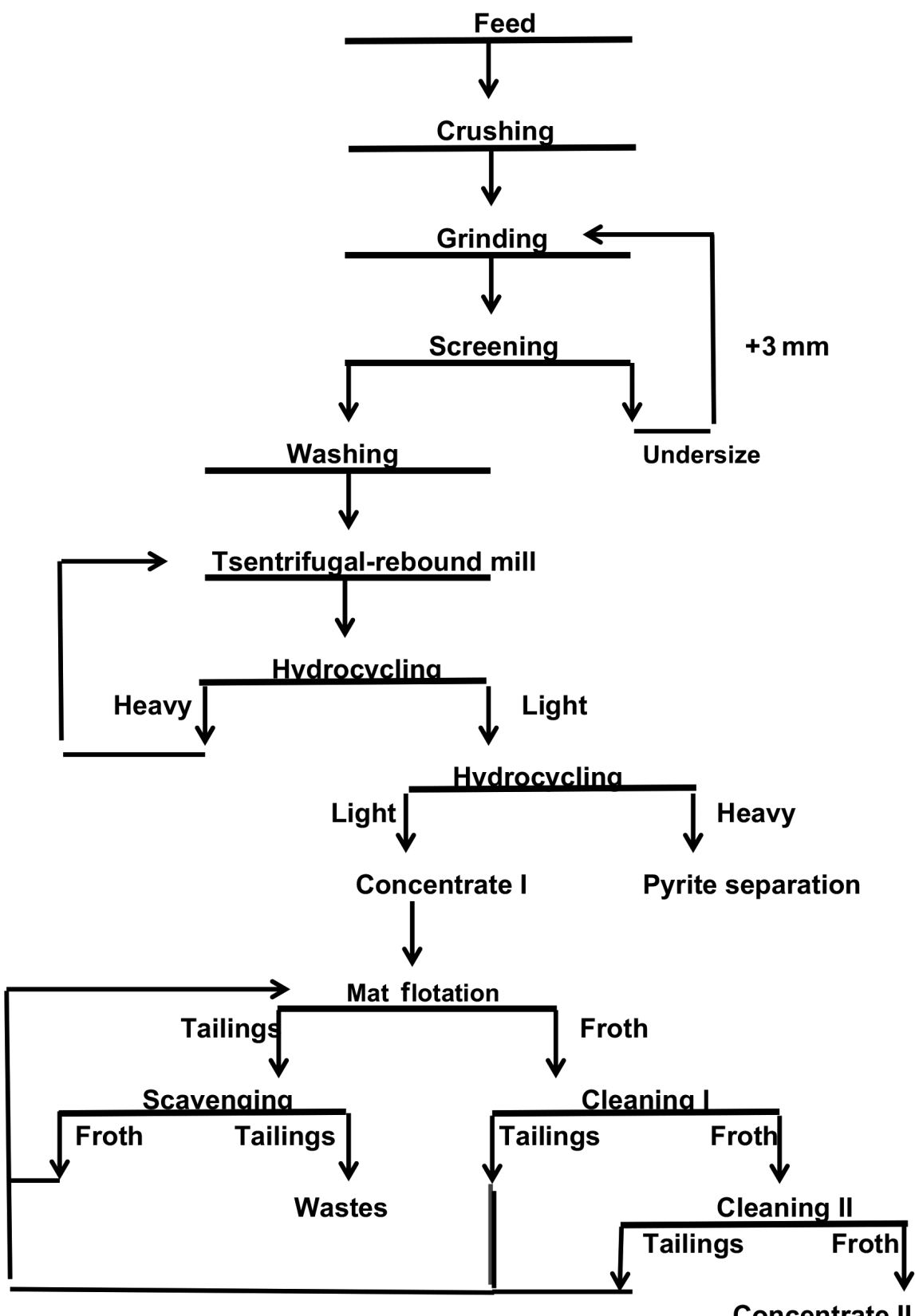

Fig. 2. A basic flowsheet for the process of separation of organic matter from argillite. 
The results obtained show that the beneficiation process can afford a product with an enhanced content of rare metals at their recovery of $70-75 \%$. The amount of material for further treatment was significantly decreased, to $20-30 \%$ of the feed material. A basic flowsheet for the process of separation of OM from argillite is shown in Figure 2. However, possibilities of using beneficiation in argillite processing, particularly with regard to complete metals recovery, had to be additionally investigated and economic analysis of the whole process had to be performed. Therefore, the further processing of argillite was carried out without prior separation of OM.

\section{Combustion of argillite with salt roasting}

As an alternative to organic matter separation during argillite processing, further its combustion with salt roasting prior to leaching was used. The ground argillite of $-6+0 \mathrm{~mm}$ was mixed with $20 \mathrm{wt} \%$ sodium chloride or sodium carbonate and roasted under oxidizing conditions in the fluidized bed at $800-850{ }^{\circ} \mathrm{C}$ [15]. An oxidizing roast converts the oxides of vanadium, molybdenum and uranium via the addition of sodium chloride or sodium carbonate to a soluble form as follows:

$$
\mathrm{V}_{2} \mathrm{O}_{5}+2 \mathrm{NaCl}+1 / 2 \mathrm{O}_{2}=2 \mathrm{NaVO}_{3}+\mathrm{Cl}_{2} \text {. }
$$

By using a carbonate, the conversion can be expressed as follows:

$$
\begin{gathered}
\mathrm{MoO}_{3}+\mathrm{Na}_{2} \mathrm{CO}_{3}=\mathrm{Na}_{2} \mathrm{MoO}_{4}+\mathrm{CO}_{2}, \\
\mathrm{UO}_{3}+3 \mathrm{Na}_{2} \mathrm{CO}_{3}+\mathrm{H}_{2} \mathrm{O}=\mathrm{Na}_{4}\left[\mathrm{UO}_{2}\left(\mathrm{CO}_{3}\right)_{3}\right]+2 \mathrm{NaOH} .
\end{gathered}
$$

Temperature control is critical because the recovery of metals into a leaching solution decreases when the combustion temperature exceeds $850{ }^{\circ} \mathrm{C}$ [16]. It should be noted that $\mathrm{NaCl}$ and $\mathrm{Na}_{2} \mathrm{CO}_{3}$ may be used in combination in the roasting process, but their additional amounts need optimization.

The yield of the roasted residue after combustion of OM was $80-85 \%$ and the contents of rare metals were increased. The average contents of rare metals in the combustion residue were the following: Mo $566 \mathrm{~g} / \mathrm{t}, \mathrm{U} 202 \mathrm{~g} / \mathrm{t}$ and $\mathrm{V} 1380 \mathrm{~g} / \mathrm{t}$.

The roasted residue was further processed by the acid and alkaline leaching of the soluble forms of rare metals. In the former case, a $20 \%$ sulfuric acid solution and in the latter case, a $20 \%$ sodium carbonate solution was used. The leaching was carried out by agitation and sedimentation-filtration under the following conditions: solid input-liquid ratio $1: 3$, temperature $100{ }^{\circ} \mathrm{C}$ for $30 \mathrm{~min}$. The recovery of metals in both cases was approximately $70-80 \%$. The acid leaching method takes advantage of the increased recovery of metals, though the alkaline (carbonate) leaching is inherently more selective than the acid one, while the majority of ions of other metals, such as iron, are insoluble 
in this case. By using sodium carbonate for salt roasting, it is possible to carry out the water leaching of the residue. The possibility of utilizing the recycling of residual salts for the roasting process needs to be studied.

\section{The recovery of rare metals from salt-roast leaching solutions}

Rare metals can be recovered from leaching solutions by using a variety of methods, including chemical precipitation and ion exchange. As rare metals molybdenum, uranium and vanadium were present in leaching solutions in low concentrations and their selective recovery was needed, the ion exchange method in column mode was applied. This enabled a high enrichment of metals in the eluent to be achieved.

As is known, the type of molybdenum ions in a leachate depends on the concentration of hydrogen ions [17]. In the $\mathrm{pH}$ range 1-6 molybdenum species exist as polyanions, at $\mathrm{pH}$ lower than 1 molybdenyl species $\mathrm{MoO}_{2}{ }^{2+}$ and at $\mathrm{pH}$ above 7 molybdate ions $\mathrm{MoO}_{4}{ }^{2-}$ predominate. Vanadium exists in a leachate of low $\mathrm{pH},<1$, as vanadyl species $\mathrm{VO}_{2}^{+}$, in the $\mathrm{pH}$ range 2-10 as polyanions and at $\mathrm{pH}$ above 10 mostly as metavanadate anions $\mathrm{VO}_{3}^{-}$. Uranium is present in sulphuric acid solutions as an anionic sulfate complex $\left[\mathrm{UO}_{2}\left(\mathrm{SO}_{4}\right)_{3}\right]^{4-}$ and in carbonate solutions as a carbonate complex $\mathrm{UO}_{2}\left(\mathrm{CO}_{3}\right)_{3}{ }^{4-}$. In a sodium hydroxide solution uranium exists in the form of an insoluble diuranate $\mathrm{Na}_{2} \mathrm{U}_{2} \mathrm{O}_{7}$.

In the recovery and separation of $\mathrm{U}$ and $\mathrm{V}$ the use of anion exchangers takes advantage of the following factors: 1) the ionic state of metals in leaching solutions; 2) high adsorption capability; 3 ) high concentration of cationic iron species. Model solutions were used to study the possibilities of recovering and separating Mo, $\mathrm{U}$ and $\mathrm{V}$ from anion-exchange resins, considering the large excess of sulfate ions and the presence of other ions such as ferric cations. A strongly basic anion-exchange resin $\mathrm{AB}-17$ with a polystyrene matrix and a functional group $\mathrm{R}_{4} \mathrm{~N}^{+}$was used in the $\mathrm{OH}$ - form. The adsorption experiments were carried out on ion-exchange columns of 80 or $165 \mathrm{~cm}$ in height and $2-3 \mathrm{~cm}$ in diameter, with an average resin volume of $4.4 \mathrm{ml}$. The solution was fed in at the top of the column at a rate of $10 \mathrm{~cm}^{3} / \mathrm{min}$. The concentrations of metals in the effluent were continuously determined during sorption and elution.

According to literature, molybdenum and uranium form anionic complexes in both strong and weak acid solutions, which have a high selectivity in terms of anion-exchange resins [18]. In contrast, the adsorption of vanadium on the anion-exchange resin is possible only from a very weak acid solution, the maximum loading of the resin occurring at $\mathrm{pH} 6-8$. Therefore, at first, the exchange adsorption of $\mathrm{V}$ from the acid leachate was investigated. Laboratory tests were carried out using an orthogonal main-effect plan (Table 2) [19-21]. The effects of different parameters on the ion exchange process of vanadium were determined using the following formula: 


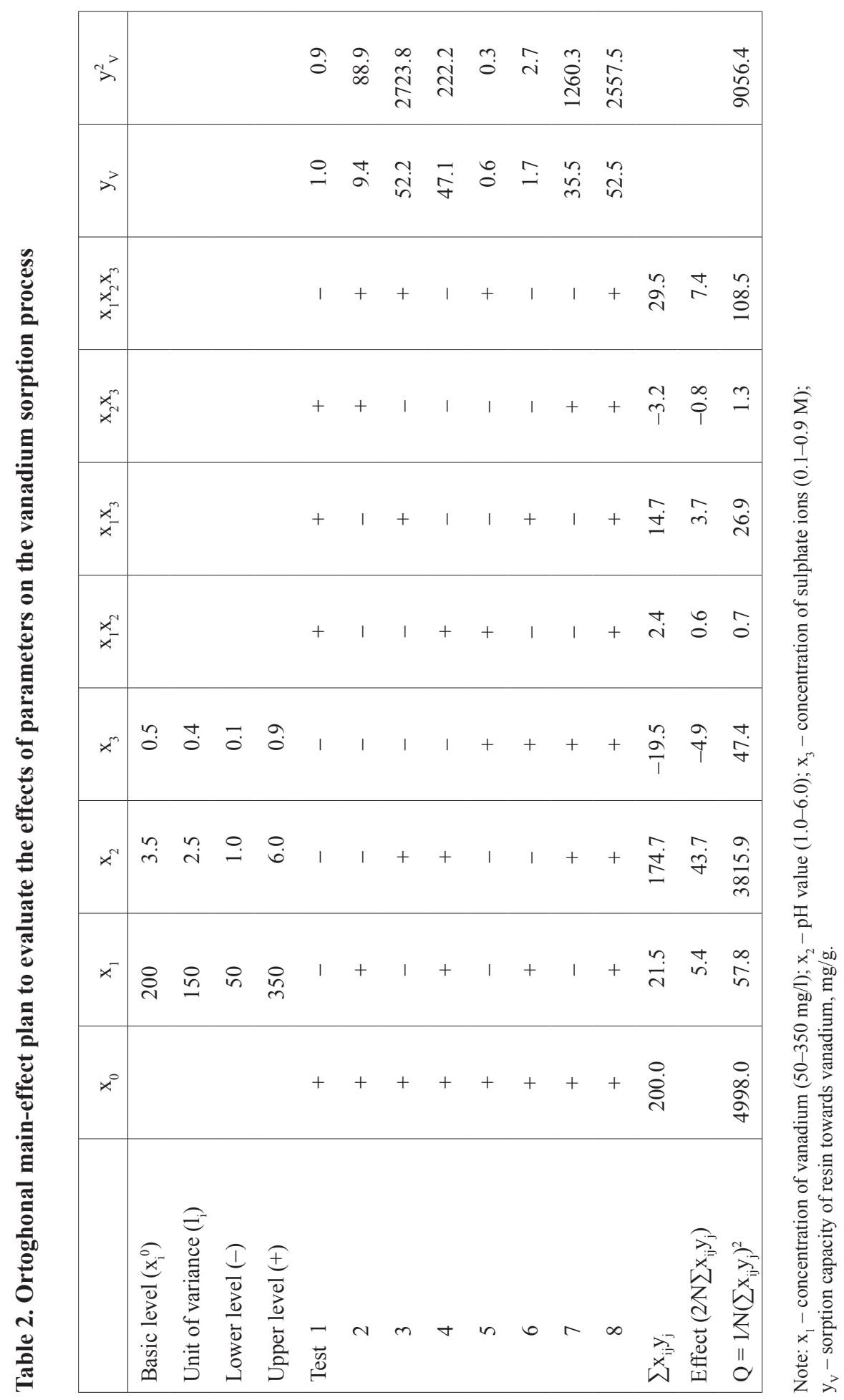




$$
\mathrm{x}_{\mathrm{i} \text { main-effect }}=2 / \mathrm{N} \sum \mathrm{x}_{\mathrm{ij}} \mathrm{y}_{\mathrm{j}} \text {, }
$$

where $x_{i}$ is the concentration of metal; $y_{j}$ is the sorption capacity of resin (complete) towards metal, $\mathrm{mg} / \mathrm{g}$ air dry resin, $\mathrm{N}$ is a test number; $\mathrm{x}_{\mathrm{ij}} \mathrm{y}_{\mathrm{j}}$ is the interaction between $\mathrm{x}_{\mathrm{ij}}$ and $\mathrm{y}_{\mathrm{j}}$. The experimental results are presented in Table 2.

The error of variables may be evaluated, assuming that interactions between the factors are negligible:

$$
\mathrm{s}^{2}=\frac{0.7+26.9+1.3+108.4}{4(\text { degrees of freedom })}=34.4 .
$$

where $\mathrm{s}^{2}$ is error variance (dispersion).

$$
\mathrm{Q}=\mathrm{s}^{2} \mathrm{~F}=34.4 \times 7.71=265.2,
$$

where $\mathrm{Q}$ is total variability (e.g. failure to reproduce treatment combinations exactly) and $\mathrm{F}$ is $\mathrm{F}$-criterion, whose values depending on the degree of freedom for a 5\% risk can be obtained from Table 2 [19, 22]. Effects Qi $>$ Q are significant.

From Table 2 it can be seen that the $\mathrm{pH}$ factor has the most significant effect on the sorption capacity of the anion exchanger:

$$
\mathrm{Q}_{2}=3815.89>265.2,
$$

where $Q_{2}$ is the variability of the sorption capacity of resin $y_{j}$ due to the change in $\mathrm{x}_{\mathrm{i}}$. The sorption capacity of the resin increases by $43.7 \mathrm{mg} / \mathrm{g}$ with $\mathrm{pH}$ increasing from -1 to +6 , while values of other factors remain on basic level.

The increase of the concentration of $\mathrm{V}$ increases the sorption capacity of the resin and the increase of the content of sulphate ions decreases it, but these effects are insignificant in a statistical sense.

Statistically insignificant are effects:

$$
\begin{array}{ll}
\text { for factor } \mathrm{x}_{1}: & \mathrm{Q}_{1}=57.8<265.2, \\
\text { for factor } \mathrm{x}_{3}: & \mathrm{Q}_{3}=47.4<265.2 .
\end{array}
$$

As seen from Table 2, the sorption capacity of the anion exchanger with respect to vanadium at a minimum $\mathrm{pH}$ of the leaching solution is very low, approximately $1 \mathrm{mg} / \mathrm{g}$ (tests $1,5,6$ ).

The breakthrough curves for the sorption of $\mathrm{V}$ at different $\mathrm{pH}$ values of the leaching solution are shown in Figure 3 and elution profiles for $\mathrm{V}$ sorption with different stripping solutions are depicted in Figure 4.

Figure 3 shows the sorption of $\mathrm{V}$ to be highly dependent on the solution $\mathrm{pH}$. The adsorbed vanadium was completely eluted with both eluents (Fig. 4) and the best strip gave a satisfactory concentration factor, about 10 .

By the sorption of vanadium from the acid leaching solution one must take into account its high content of $\mathrm{Fe}^{2+}$ and $\mathrm{Fe}^{3+}$ ions. The sulphate complex of 


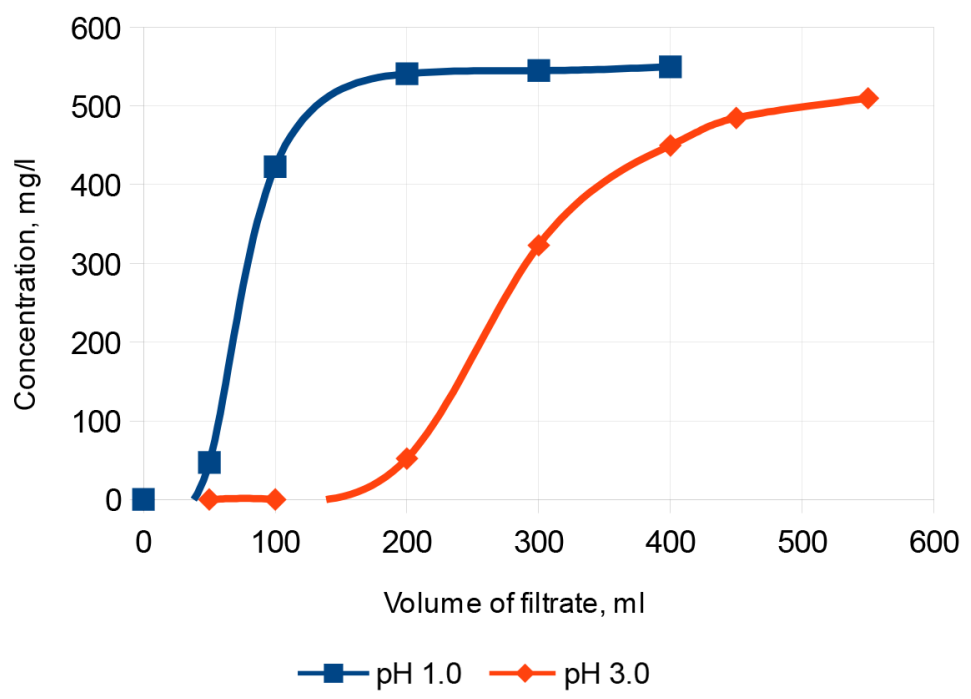

Fig. 3. Breakthrough curves for the sorption of vanadium by anion exchanger AB-17 at different $\mathrm{pH}$ values of the leaching solution.

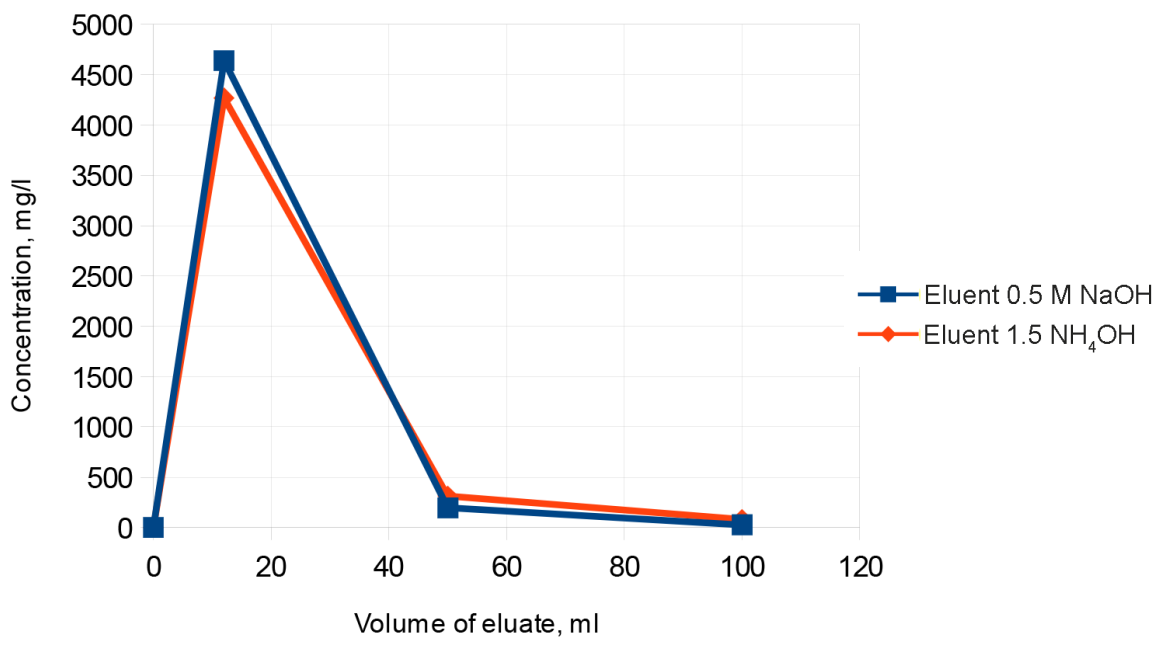

Fig. 4. Elution profiles of vanadium from anion exchanger AB-17.

iron(III), $\left[\mathrm{Fe}\left(\mathrm{SO}_{4}\right)_{2}\right]^{-}$, may be adsorbed on the anion exchanger together with vanadium anions, which may significantly influence the adsorptivity of V. To avoid the precipitation of iron hydroxide, the effect of iron ions at $\mathrm{pH} 1.5$ was examined. The results are presented in Table 3. 


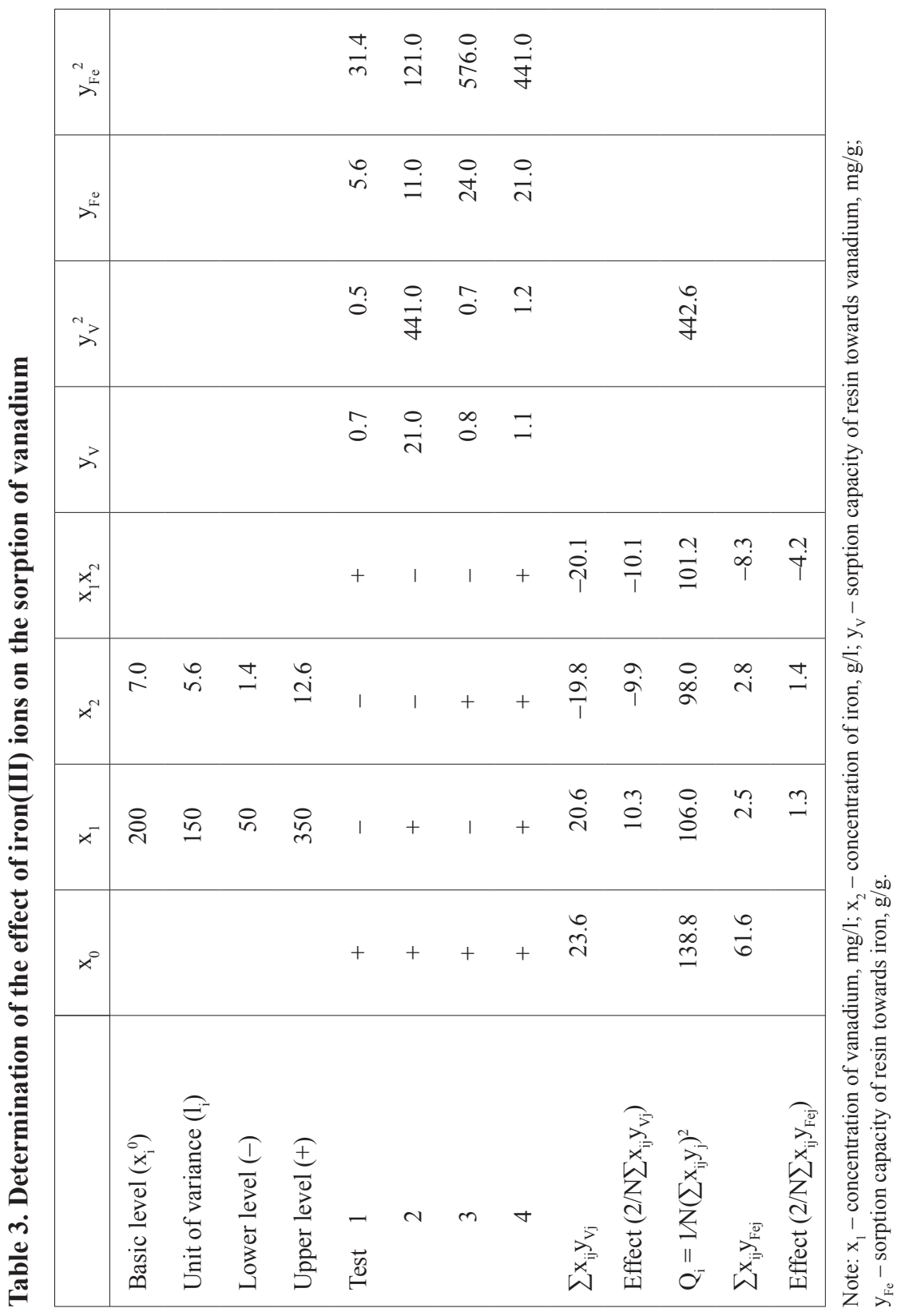


Table 3 reveals that the sorption capacity of the resin towards vanadium depends strongly on the concentration of iron (effect is $-9.9 \mathrm{mg} / \mathrm{g}$ ) and that its sorption at a high concentration of iron ions is negligible, approximately $1.0 \mathrm{mg} / \mathrm{g}$ (tests 3, 4). Tests 3 and 4 also give evidence of a marked sorption of iron on the anion exchanger. The presence of iron(II) ions causes vanadium to appear in its tetravalent state, $\mathrm{VO}^{2-}$, which exhibits no adsorptivity on the anion exchanger.

Based on the results presented in Tables 2 and 3, it can be concluded that at low $\mathrm{pH}$ and in the presence of iron in high concentrations, the sorption of vanadium from acid solutions on the anion exchanger is insignificant.

Thereafter, the sorption of uranium and molybdenum from acid solutions on the anion exchanger was first investigated in a wide range of $\mathrm{pH}$ values, 1.0-4.0. The effects of various parameters, namely the concentrations of molybdenum $\left(\mathrm{x}_{1}\right)$ and uranium $\left(\mathrm{x}_{2}\right)$ as well as solution $\mathrm{pH}\left(\mathrm{x}_{3}\right)$, were evaluated. The results obtained on the basis of the factorial main-effect plan presented in Table 4 show that the effects of uranium concentration $\left(\mathrm{x}_{2}\right)$ and $\mathrm{pH}$ value $\left(\mathrm{x}_{3}\right)$ on the sorption of $\mathrm{U}$ are significant and relatively close, $-49.6 \mathrm{mg} / \mathrm{g}$ and $48.5 \mathrm{mg} / \mathrm{g}$, respectively. The concentration of Mo has a considerably higher influence on the sorption of $U$, effect $x_{1}=-69.6 \mathrm{mg} / \mathrm{g}$.

The effects of concentrations $\mathrm{x}_{1}$ and $\mathrm{x}_{2}$ on the sorption of molybdenum are significant, $74.2 \mathrm{mg} / \mathrm{g}$ and $-64.7 \mathrm{mg} / \mathrm{g}$, respectively, but the effect of $\mathrm{pH}$ value $\left(\mathrm{x}_{3}\right)$ is essentially higher, $125.5 \mathrm{mg} / \mathrm{g}$.

The results of tests showed the adsorptivity of Mo and $U$ to be highly dependent on the solution $\mathrm{pH}$ value. Considering also the fact that the $\mathrm{pH}$ of acidic leaching solutions was low, the subsequent studies were focused on the metals adsorptivity at lower $\mathrm{pH}$ values, in the range of 1.0-2.0 (factor $\left.\mathrm{x}_{3}\right)$. The values of the levels for the factors of Mo $\left(\mathrm{x}_{1}\right)$ and $\mathrm{U}\left(\mathrm{x}_{2}\right)$ concentrations were low, $100 \mathrm{mg} / \mathrm{l}^{-}$(minus), and high, $500 \mathrm{mg} / \mathrm{l}$ (plus), respectively (Table 5).

In assessing the error variance, it was assumed that interactions between the factors were close to zero. Based on 4 degrees of freedom, the error variance $\left(\mathrm{s}^{2}\right)$ with respect to molybdenum sorption is:

$$
\begin{gathered}
\mathrm{s}^{2}=(163.8+0.08+66.1+2.2) / 4=58.0, \\
\mathrm{Q}_{\mathrm{Mo}}=\mathrm{s}^{2} \mathrm{~F}=58.0 \times 7.71=447.2,
\end{gathered}
$$

where F-criterion is $7.71[19,22]$.

The error variance with respect to uranium sorption is:

$$
\begin{gathered}
\mathrm{s}^{2}=(1851.4+313.8+53.6+475.8) / 4=673.7, \\
\mathrm{Q}_{U}=\mathrm{s}^{2} \mathrm{~F}=673.2 \times 7.71=5193.8
\end{gathered}
$$

The results presented in Table 5 give evidence of that the concentration factor has the highest effect on the ion exchange sorption of molybdenum:

$$
\mathrm{Q}_{1 \mathrm{Mo}}=9166.6>447.2 \text {. }
$$




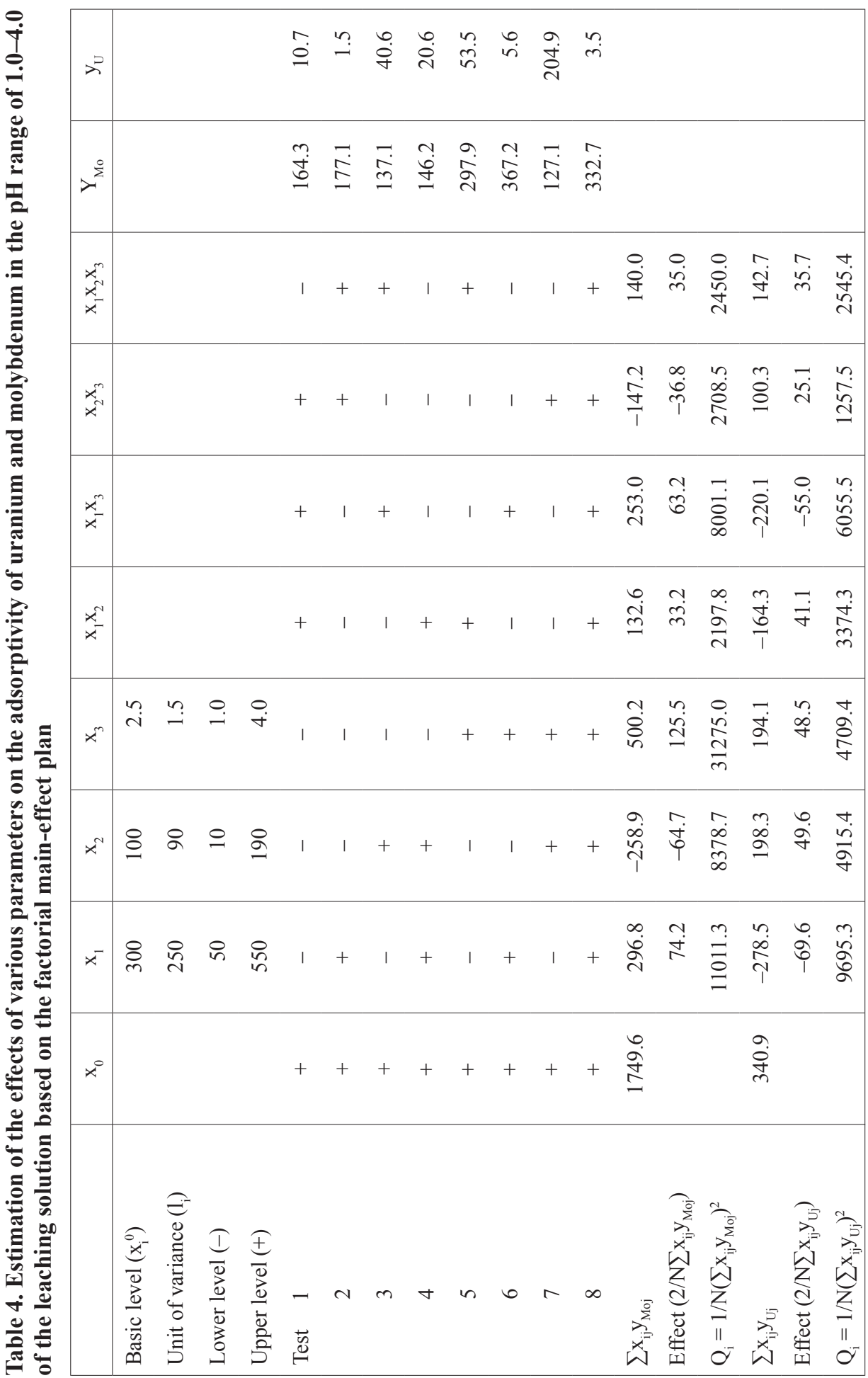




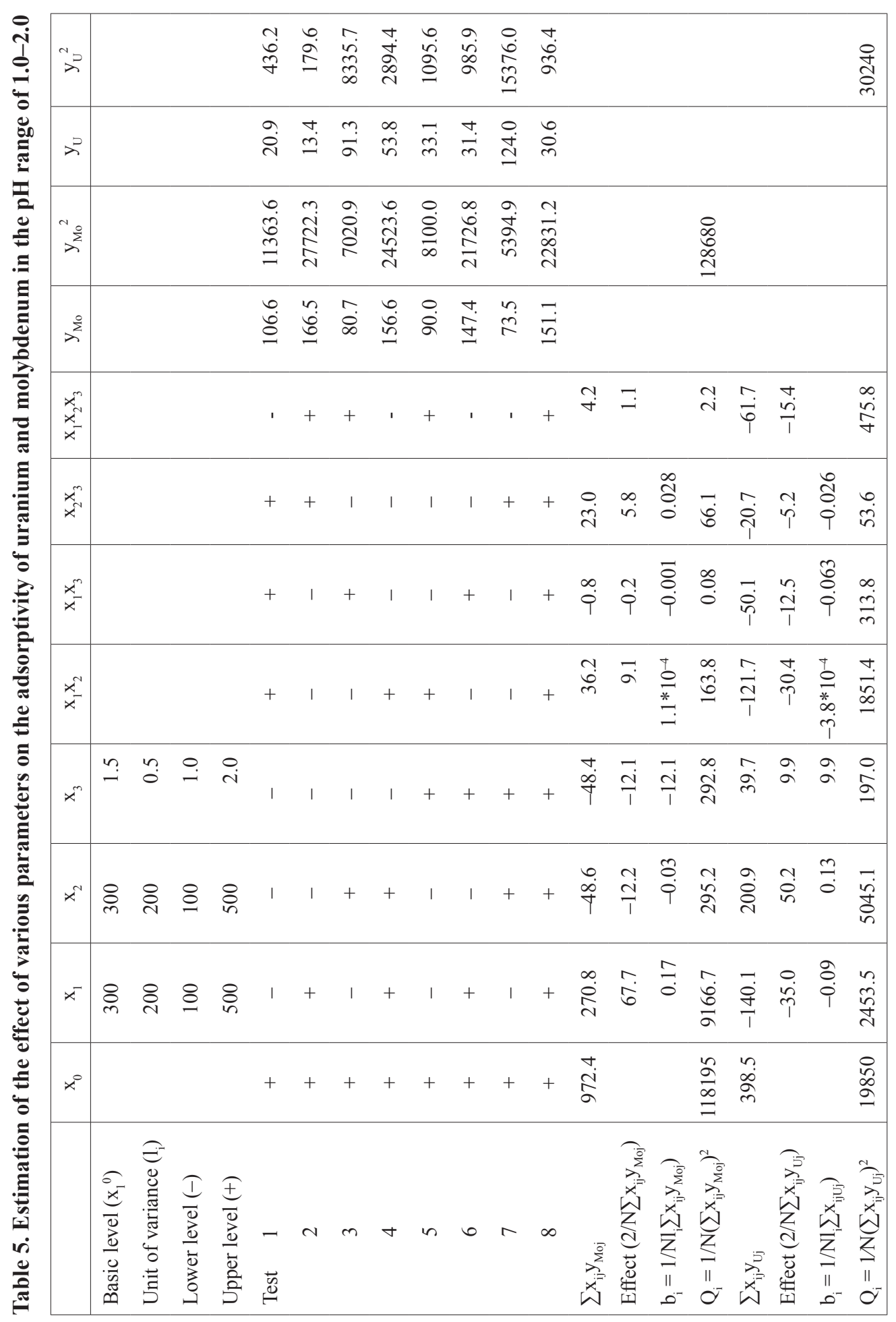


The increase in molybdenum concentration from 100 to $500 \mathrm{mg} / \mathrm{l}$ increases the sorption capacity of the resin towards Mo to $67.7 \mathrm{mg} / \mathrm{g}$. The increase of uranium concentration in the same range increases the sorption capacity of the resin towards $U$ to $50.2 \mathrm{mg} / \mathrm{g}$. The resin's sorption capacity with respect to Mo is nearly independent of the concentration of uranium (effect $-12.2 \mathrm{mg} / \mathrm{g}$ ):

$$
\mathrm{Q}_{3 \mathrm{U}}=295.2<\mathrm{Q}_{\mathrm{Mo}} \text {. }
$$

At the same time, the resin's sorption capacity towards U depends on the concentration of molybdenum (effect $-35.0 \mathrm{mg} / \mathrm{g}$ ). The effect of the $\mathrm{pH}$ factor on the sorption of both metals is insignificant. Tests 2, 4, 6 and 8 demonstrate that the resin's sorption capacity with respect to Mo is higher, approximately $150 \mathrm{mg} / \mathrm{g}$, at its high concentration in the solution $(+)$. The resin exhibits a maximum sorption capacity towards uranium, approximately $120 \mathrm{mg} / \mathrm{g}$, in test 7 where the $\mathrm{U}$ concentration is high $(+)$ and that of Mo low $(-)$. Due to the high values of Mo and $U$ concentration effects, their interactions $\mathrm{x}_{1} \mathrm{x}_{2}$ are also high, respectively 36.2 and $-30.4 \mathrm{mg} / \mathrm{g}$.

In the studied range of parameters the sorption capacity of the anion exchanger towards molybdenum can be calculated on the basis of the data presented in Table 5 by using the following formula:

$$
\begin{gathered}
\mathrm{y}_{\text {Мо }}=121.5+0.17\left(\mathrm{x}_{1}-300\right)-0.030\left(\mathrm{x}_{2}-300\right)-12.1\left(\mathrm{x}_{3}-1.5\right)+1.1 \times 10^{-4}\left(\mathrm{x}_{1}-300\right) \\
\left(\mathrm{x}_{2}-300\right)-0.001\left(\mathrm{x}_{1}-300\right)\left(\mathrm{x}_{3}-1.5\right)+0.028\left(\mathrm{x}_{2}-300\right)\left(\mathrm{x}_{3}-1.5\right) .
\end{gathered}
$$

Analogously to the above formula, the sorption capacity of the anion exchanger with respect to uranium can be calculated.

Figures 5, 6 and 7 depict the breakthrough curves for the sorption of Mo and $U$ at their different concentrations in feed solutions. From the figures it can be seen that regardless of these concentrations, the breakthrough for both metals began at the same time.

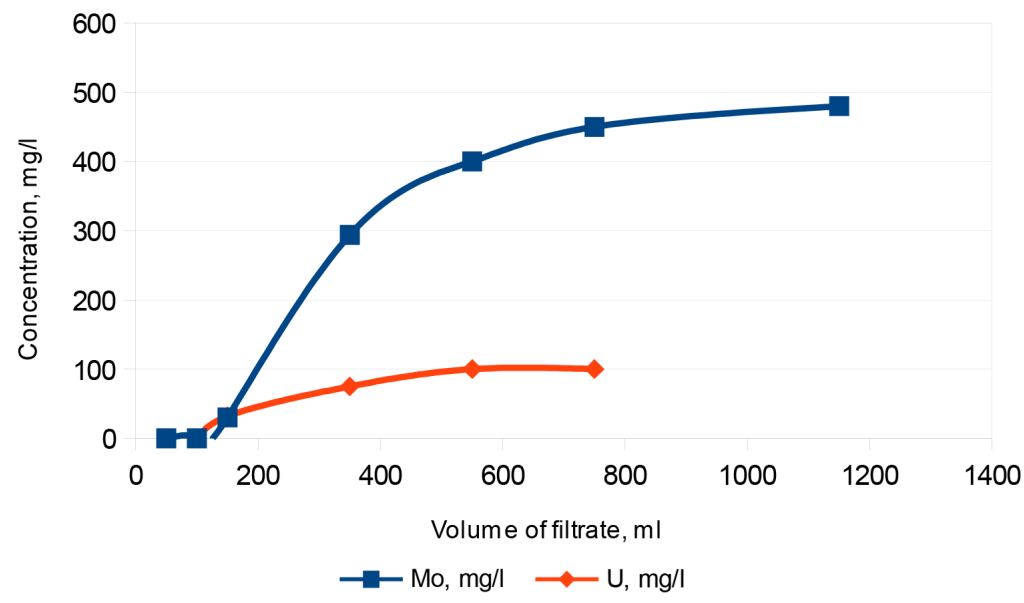

Fig. 5. Breakthrough curves for the sorption of molybdenum and uranium by anion exchanger AB-17 at their different concentrations in feed solutions, $\mathrm{pH} 2.0$ (test 6, Table 5). 


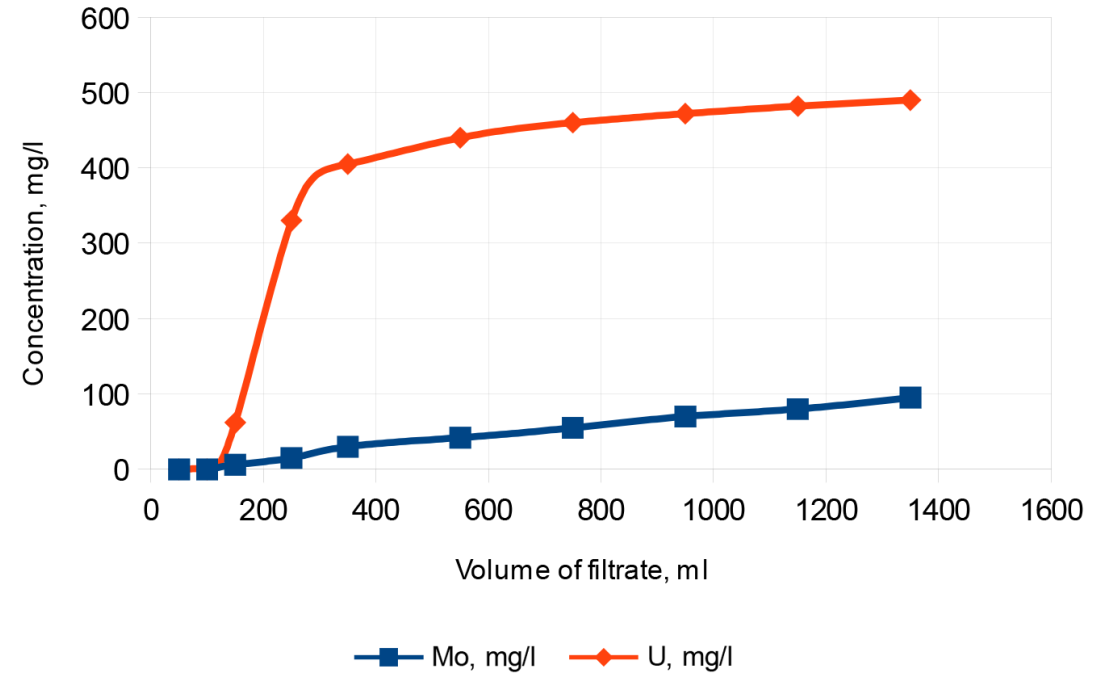

Fig. 6. Breakthrough curves for the sorption of molybdenum and uranium in significant excess of $U$ ions in the feed solution, $\mathrm{pH} 2.0$ (test 7, Table 5).

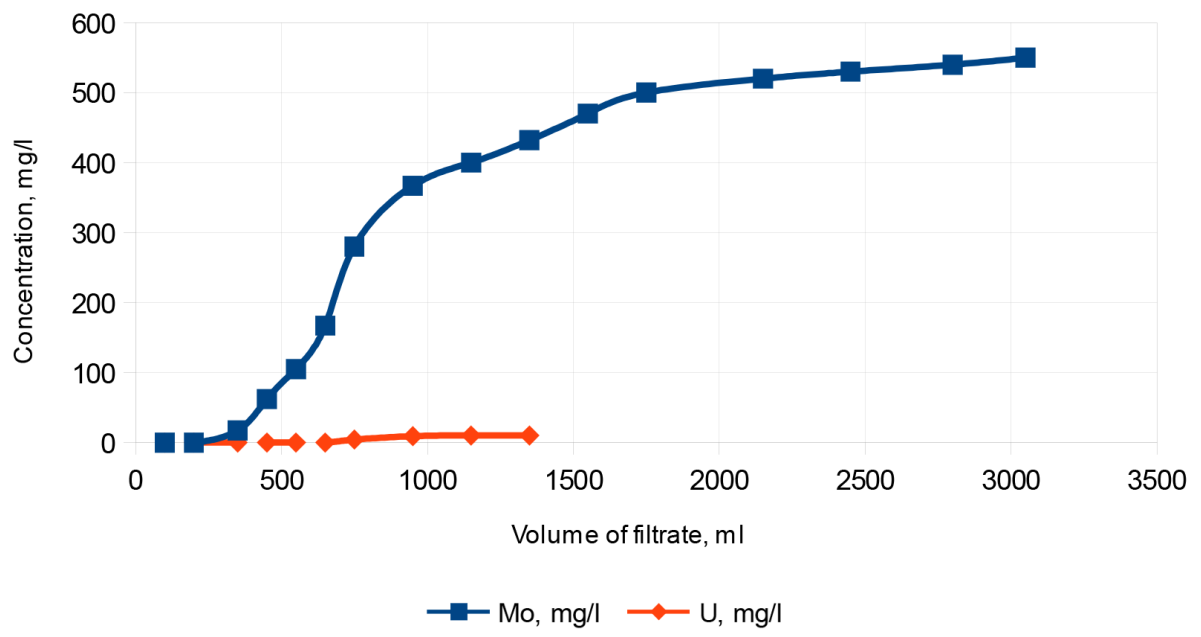

Fig. 7. Breakthrough curves for the sorption of molybdenum and uranium in significiant excess of Mo ions in the feed solution, $\mathrm{pH} 4.0$ (test 6, Table 4).

The dependence of the anion-exchange resin's sorption capacity with respect to $U$ on the concentrations of molybdenum and uranium in feed solutions is illustrated in Figure 8. 


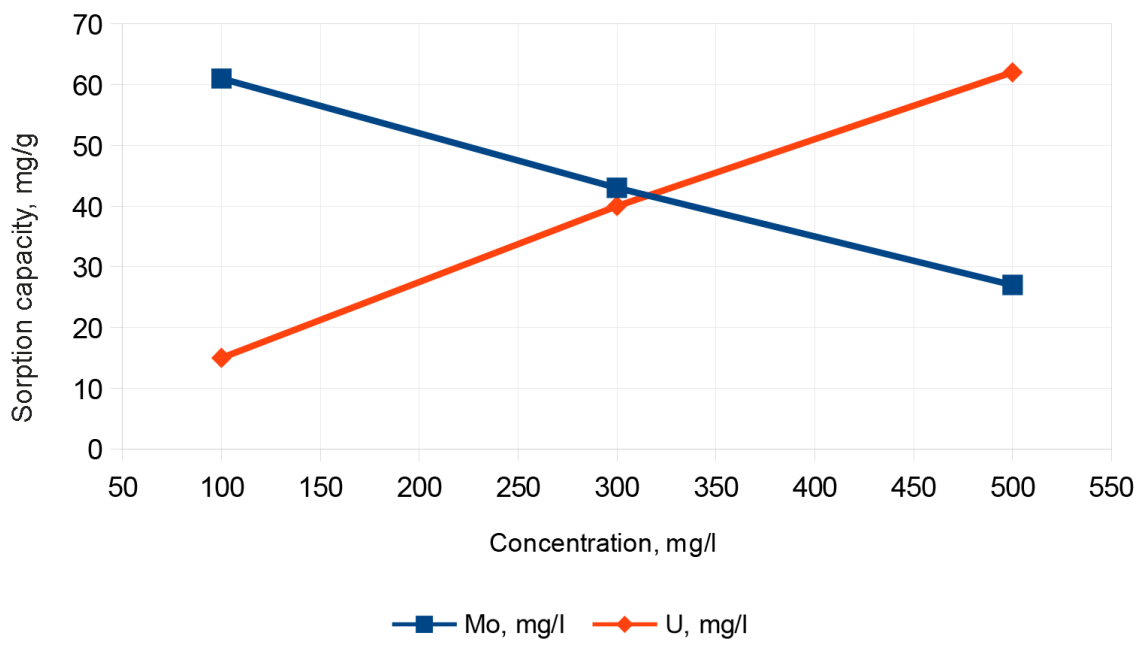

Fig. 8. The dependence of the sorption capacity of anion exchanger AB-17 with respect to uranium on the feed concentrations of molybdenum and uranium.

Considering the large excess of iron(II) ions in acid leaching solutions, the adsorptivity of molybdenum and uranium was examined in the presence of $\mathrm{FeSO}_{4}$. In this case, an augmenting factorial plan for determination of main effects was used on an assumption that interactions between the factors were negligible [23]. To the factorial plan with 8 tests (Table 5) a block with the fourth factor $\mathrm{x}_{4}\left(\mathrm{FeSO}_{4}\right.$ concentration $\left.20 \mathrm{~g} / \mathrm{l}\right)$ was added (Table 6$)$. The effects of parameters $x_{1}, x_{2}$ and $x_{3}$ calculated on the basis of 12 tests ( 4 tests in the presence of $\mathrm{FeSO}_{4}$ ) were close to those presented in Table 5. However, the presence of $\mathrm{FeSO}_{4}$ had a strong influence on the resin's sorption capacity towards molybdenum, the effect of $\mathrm{x}_{4}$ being $-61.3 \mathrm{mg} / \mathrm{g}$. At the same time, the effect of $x_{4}$ on the adsorption of $U$ was considerably lower, $-13.4 \mathrm{mg} / \mathrm{g}$ (Table $5, \mathrm{y}_{\mathrm{u}}$ ). For example, Table 5 reveals that at low metals concentrations and $\mathrm{pH}$ values (test 1 ) the resin's sorption capacity regarding $\mathrm{Mo}$ and $\mathrm{U}$ is respectively $106.6 \mathrm{mg} / \mathrm{g}$ and $20.9 \mathrm{mg} / \mathrm{g}$, but in the presence of $\mathrm{FeSO}_{4}$, this capacity is $44.5 \mathrm{mg} / \mathrm{g}$ and $21.1 \mathrm{mg} / \mathrm{g}$, respectively (test 9, Table 6). However, the influence of $\mathrm{FeSO}_{4}$ on the resin's sorption capacity with respect to $\mathrm{U}$ is higher at its high concentration, decreasing from $53.8 \mathrm{mg} / \mathrm{g}$ (test 4, Table 5) to $33.8 \mathrm{mg} / \mathrm{g}$ (test 10, Table 6).

For stripping the selective elution under column loading conditions was used. Figure 9 depicts the selective elution of Mo and $U$ from anion exchanger $\mathrm{AB}-17$ by using respectively $\mathrm{HCl}$ and $2.0 \mathrm{M} \mathrm{NaOH}$ solutions. Data on the previous sorption of metals are presented in Table 4 (test 7). At first uranium was eluted with dilute hydrochloric acid $(0.3 \mathrm{M})$, then molybdenum was eluted with a $2.0 \mathrm{M} \mathrm{NaOH}$ solution. In the elution process the concentration factor of 20 for $U$ and 80 for Mo were achieved. 
Table 6. A block of tests for determination of the influence of iron(II) on the sorption of molybdenum and uranium

\begin{tabular}{|l|c|c|c|c|c|c|c|}
\hline & $\mathrm{x}_{0}$ & $\mathrm{x}_{1}$ & $\mathrm{x}_{2}$ & $\mathrm{x}_{3}$ & $\mathrm{x}_{4}$ & $\mathrm{y}_{\mathrm{Mo}}$ & $\mathrm{y}_{\mathrm{U}}$ \\
\hline Test 9 & + & - & - & - & + & 44.5 & 21.1 \\
& + & + & + & - & + & 111.8 & 33.8 \\
10 & + & + & - & + & + & 57.0 & 28.9 \\
12 & + & - & + & + & + & 27.7 & 61.6 \\
$\sum \mathrm{x}_{\mathrm{ij}} \mathrm{y}_{\mathrm{Moj}}$ & 1213.4 & 366.6 & -10.6 & -120.0 & -243.1 & & \\
Effect $\left(2 / \mathrm{N} \sum \mathrm{x}_{\mathrm{ij}} \mathrm{y}_{\mathrm{Moj}}\right)$ & & 61.2 & -1.8 & -20.0 & -60.7 & & \\
$\sum \mathrm{x}_{\mathrm{ij}} \mathrm{y}_{\mathrm{Uj}}$ & 543.9 & -160.1 & 246.3 & -12.8 & -84.7 & & \\
Effect $\left(2 / \mathrm{N} \sum \mathrm{x}_{\mathrm{ij}} \mathrm{y}_{\mathrm{Uj}}\right)$ & & -26.7 & 41.1 & -1.1 & -21.2 & & \\
\hline
\end{tabular}

(a)

(b)

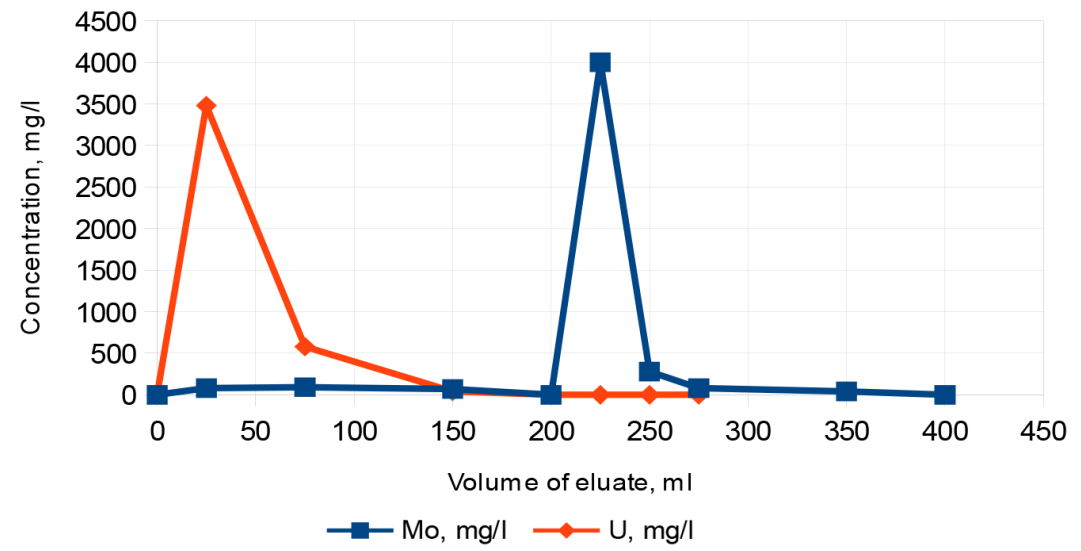

Fig. 9. The selective elution of uranium and molybdenum from anion exchanger AB17 by using $0.3 \mathrm{M} \mathrm{HCl}$ (a) and $2.0 \mathrm{M} \mathrm{NaOH}$ (b).

Figure 10 (data on previous sorption from test 3, Table 4) shows the elution profiles of Mo and U under column loading conditions at large excess of Mo ions, indicating their good separation - via the acidic elution approximately $100 \%$ of sorbed uranium was removed. Stripping with a weak solution of hydrochloric acid $(0.3 \mathrm{M} \mathrm{HCl})$ recovered but an insignificant amount of $\mathrm{Mo}$, approximately $96 \%$ of it was eluted with an alkaline eluent. Using a stronger eluent $(0.5 \mathrm{M} \mathrm{HCl})$ slightly increased the amount of Mo in an acidic eluent (Fig. 11), however, this depended on its amount sorbed. 
(a)

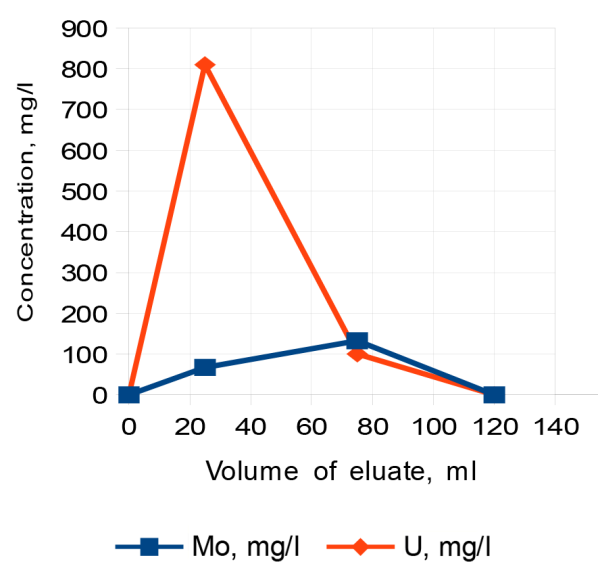

(b)

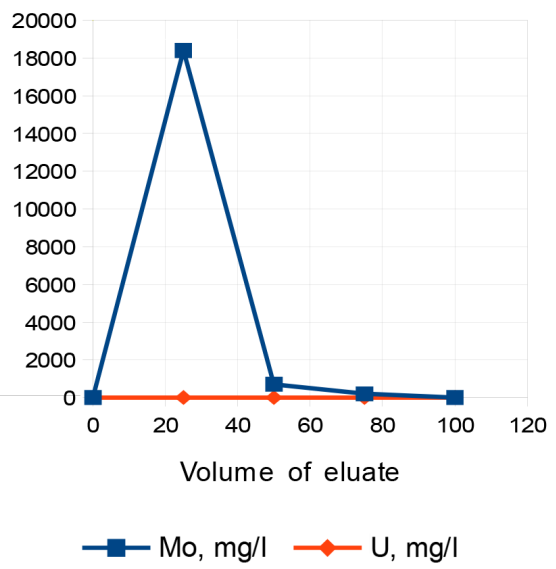

Fig. 10. Elution profiles of uranium and molybdenum under column loading conditions at large excess of Mo ions by using $0.5 \mathrm{M} \mathrm{HCl}$ (a) and $2.0 \mathrm{M} \mathrm{NaOH}$ (b) as eluates.

(a)

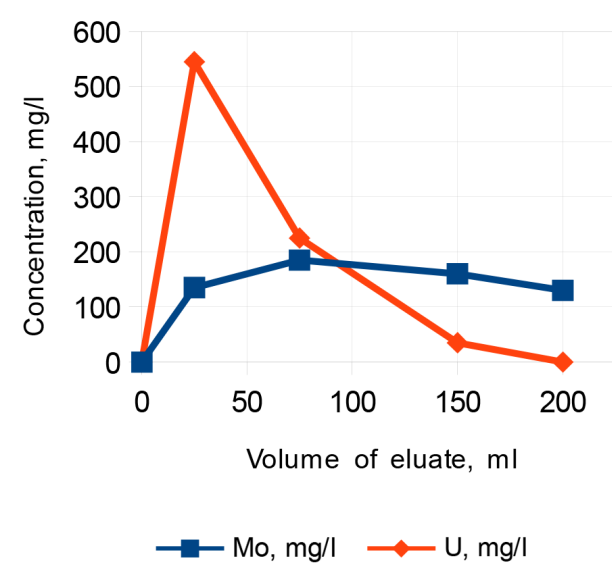

(b)

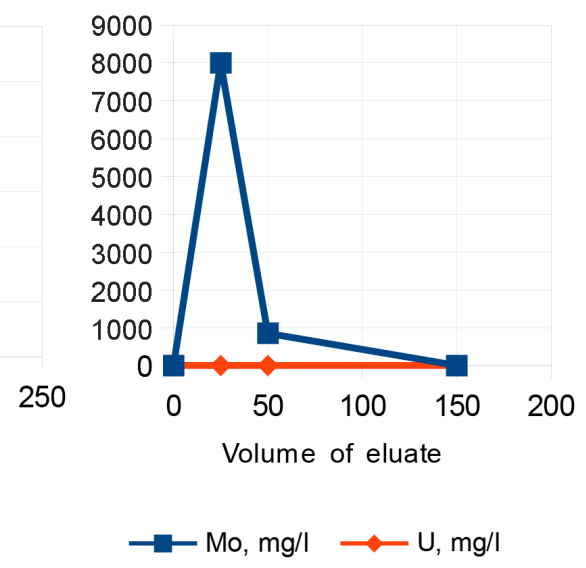

Fig. 11. Elution profiles of molybdenum and uranium from anion exchanger AB-17 by using $0.5 \mathrm{M} \mathrm{HCl}$ for the stripping of $\mathrm{U}$.

Considering the large excesss of iron ions and the low value of $\mathrm{pH}$, the recovery of molybdenum, uranium and vanadium from acid leachates by anionic resins is very complicated. Two liters of the solution from the percolated leaching of sulphonated argillite ash was passed through a column of the strongly basic anionic resin AB-17 at a resin volume of $80 \mathrm{ml}$ and flow rate of $5.0 \mathrm{ml} \mathrm{min}{ }^{-1}$ [5]. The solution contained $65.8 \mathrm{mg} / 1 \mathrm{of} \mathrm{U}, 85.5 \mathrm{mg} / \mathrm{lof}$ Mo, $571.8 \mathrm{mg} / \mathrm{l}$ of $\mathrm{V}$ and $44.0 \mathrm{~g} / \mathrm{l}$ of $\mathrm{Fe}_{2} \mathrm{O}_{3}$, and its $\mathrm{pH}$ was adjusted to 1.5 . On the resin, $131.6 \mathrm{mg}$ of $\mathrm{U}(100 \%), 98.6 \mathrm{mg}$ of Mo $(58 \%)$ and $3.71 \mathrm{~g}$ of iron 
$(12.0 \%)$ was adsorbed. No vanadium was adsorbed under given conditions. The first stripping with dilute sulfuric acid removed iron ions from the resin. Then uranium and molybdenum were selectively eluted with $1 \mathrm{M} \mathrm{HCl}$ and $2 \mathrm{M}$ $\mathrm{NaOH}$ solutions, respectively. The elution profiles of $\mathrm{Fe}$, and of $\mathrm{Mo}$ and $\mathrm{U}$ are shown in Figures 12 and 13, respectively.

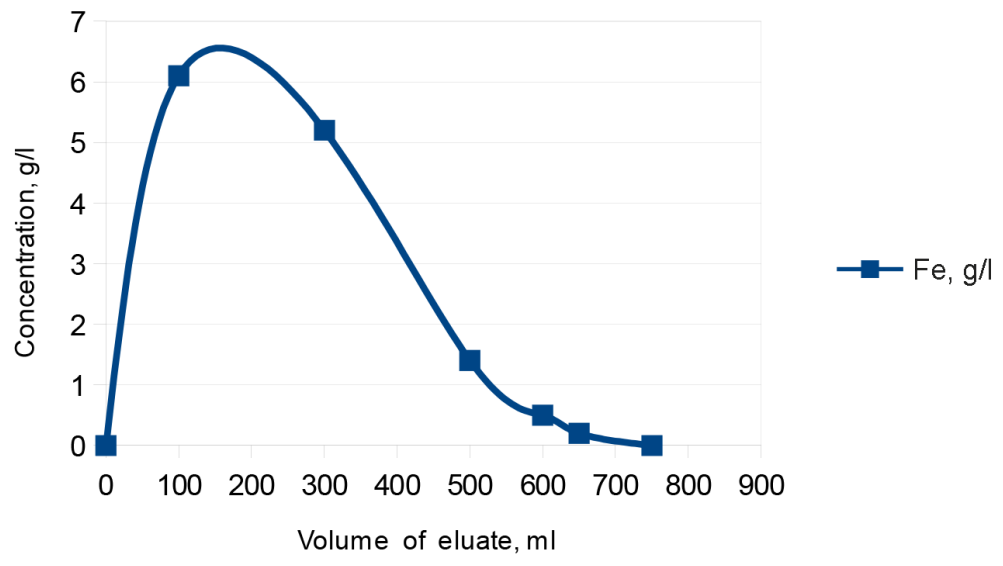

Fig. 12. The removal of iron adsorbed on the anion-exchange resin by using $0.5 \mathrm{M}$ $\mathrm{H}_{2} \mathrm{SO}_{4}$.

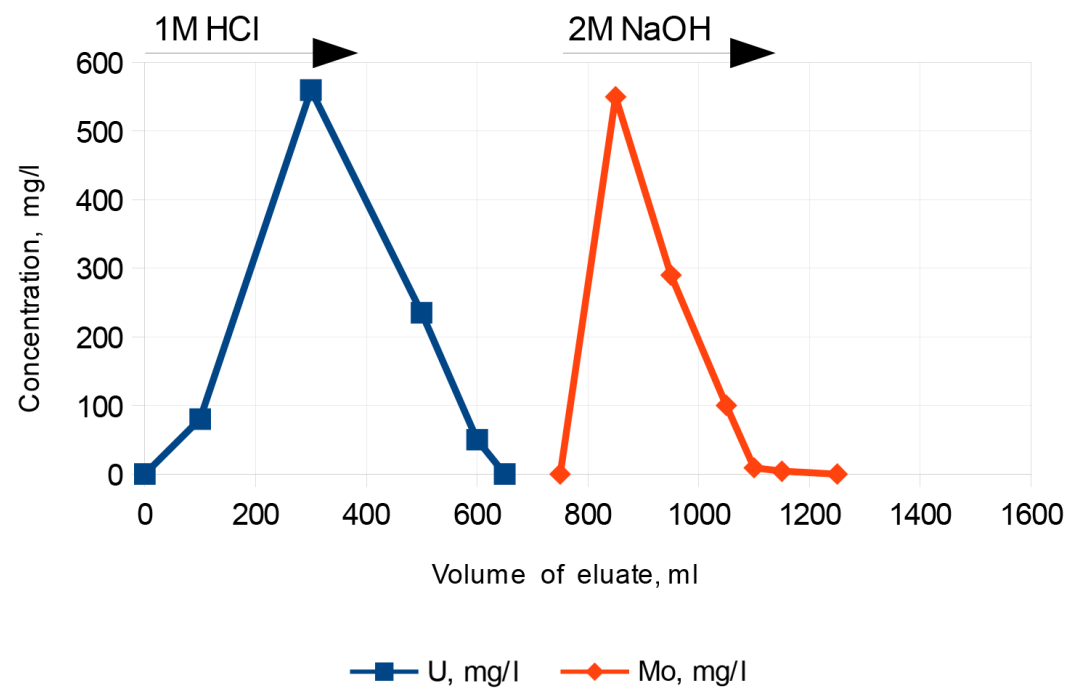

Fig. 13. The recovery of uranium and molybdenum from the sulphonated argillite ash leaching solution by the selective elution [5]. 
As shown above, the separation of vanadium from acid leachates by using ion exchange is not effective, therefore its precipitation with iron is proposed. For this purpose, the $\mathrm{pH}$ of the solution after the recovery of $\mathrm{U}$ and Mo by the anion exchanger is raised to 7 , followed by the precipitation of iron hydroxide together with $\mathrm{V}$ and Mo remaining in the solution. The treatment of the precipitate with alkaline reagents converts vanadium to water-soluble species, unlike iron, which forms an insoluble hydroxide. Optimal conditions for the hot alkaline leaching of the iron precipitate $(0.5 \mathrm{~h})$ are given in Table 7.

The data in Table 7 are indicative of a very high efficiency of leaching, up to $95-98.5 \%$ for the vanadium contained in iron hydroxide by using the solution of $\mathrm{NaOH}$ or $\mathrm{Na}_{2} \mathrm{CO}_{3}$. Further the separation of $\mathrm{V}$ may be performed using the anion exchange method whose optimal conditions are given above.

Table 7. The recovery of vanadium by the hot alkaline leaching of the iron precipitate

\begin{tabular}{|c|c|c|c|c|}
\hline Reagent & Filtrate, $\mathrm{ml}$ & Content, $\mathrm{mg} \mathrm{l}^{-1}$ & Amount, mg & Recovery, \% \\
\hline \multicolumn{5}{|l|}{$5 \% \mathrm{NaOH}$} \\
\hline 1. stage & 450 & 220.0 & 99.0 & \\
\hline 2. stage & 160 & 85.3 & 13.7 & \\
\hline & & & 112.7 & 95.5 \\
\hline \multicolumn{5}{|l|}{$2 \% \mathrm{NaOH}$} \\
\hline 1. stage & 480 & 178.2 & 85.6 & \\
\hline 2. stage & 480 & 73.9 & 35.5 & \\
\hline & & & 121.1 & 100.0 \\
\hline \multicolumn{5}{|l|}{$1 \% \mathrm{NaOH}$} \\
\hline 1. stage & 480 & 131.2 & 63.0 & \\
\hline 2. stage & 210 & 0.0 & 0.0 & \\
\hline & & & 63.0 & 53.4 \\
\hline \multicolumn{5}{|l|}{$10 \% \mathrm{Na}_{2} \mathrm{CO}_{3}$} \\
\hline 1. stage & 350 & 149.1 & 52.2 & \\
\hline \multirow[t]{2}{*}{ 2. stage } & 210 & 94.4 & 19.8 & \\
\hline & & & & 61.0 \\
\hline \multicolumn{5}{|l|}{$5 \% \mathrm{Na}_{2} \mathrm{CO}_{3}$} \\
\hline 1. stage & 420 & 119.5 & 50.1 & \\
\hline 2. stage & 440 & 105.0 & 46.2 & \\
\hline & & & 96.3 & 81.6 \\
\hline
\end{tabular}


A general flowsheet for the process of recovery of Mo, $\mathrm{U}$ and $\mathrm{V}$, which was constructed on the basis of the laboratory test results, is shown in Figure 14.

This flowsheet does not include the separation process of OM, whose detailed scheme is shown in Figure 1.

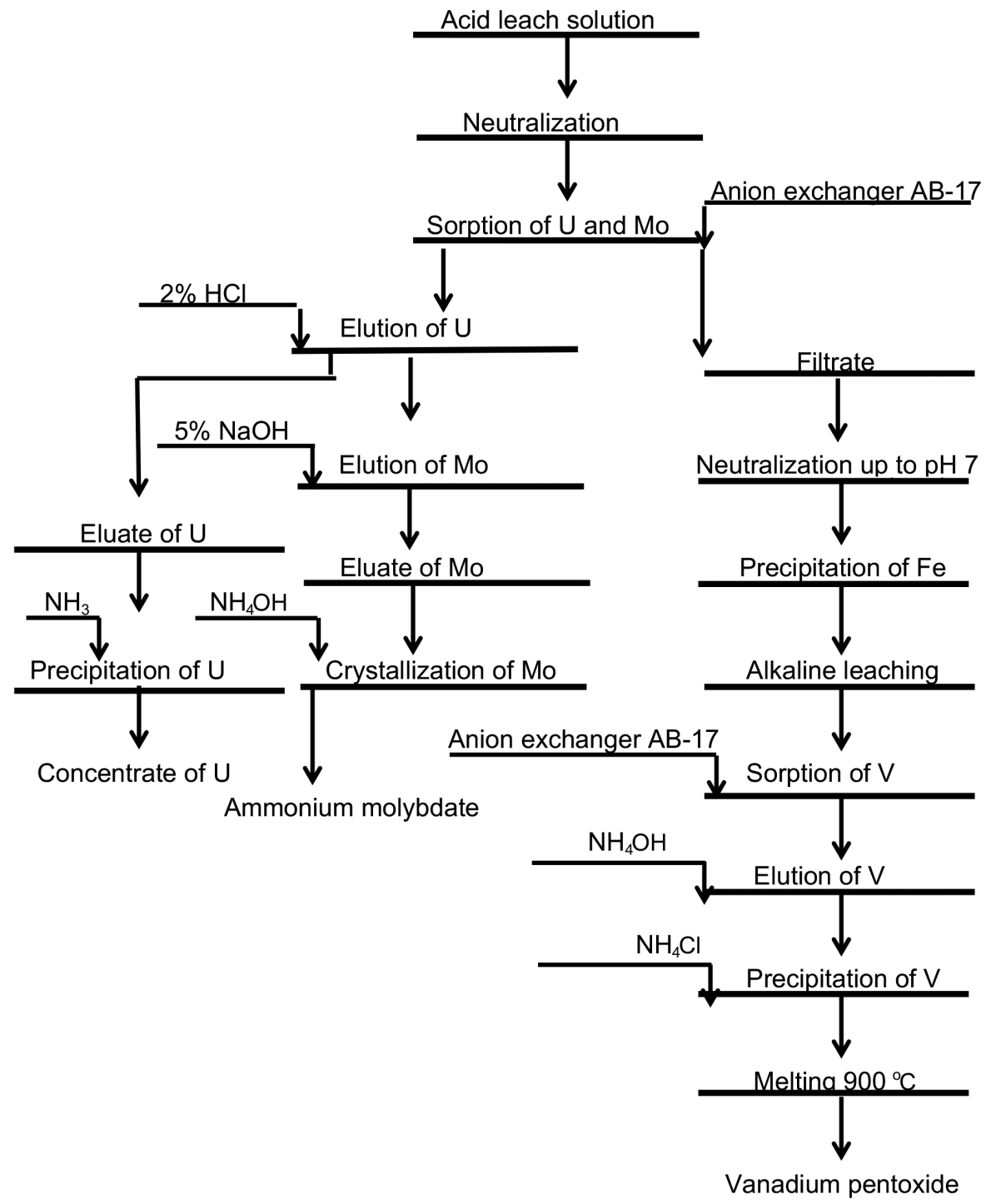

Fig. 14. A general flowsheet for the process of recovery of molybdenum, uranium and vanadium from the argillite leaching solution by anion exchange. 
The overall metals recovery process may be divided into the following stages:

1. Combustion with salts. It is offered that in this stage, an additive $\mathrm{NaCl}$ or $\mathrm{Na}_{2} \mathrm{CO}_{3}$ and a temperature range of $800-850{ }^{\circ} \mathrm{C}$ be used, while this range may need optimization. As a feed material, ground argillite was used.

2. Leaching with the use of a weak acid or alkaline solution (10-20\%).

3. Selective recovery of uranium and molybdenum by the anion exchange process.

4. Precipitation of iron hydroxide with vanadium.

5. Leaching of the iron precipitate with an alkaline solution.

6. Recovery of vanadium by the anion exchange process.

7. Precipitation of molybdenum, uranium and vanadium from elution solutions and refining to high-purity products.

\section{Conclusions}

Based on the results of the study, the following conclusions are drawn:

1. For the processing of argillite two variants have been presented: 1) separation of organic matter together with allied metals and 2) roasting combustion of ground argillite with salts without prior separation of organic matter.

2. The separation of organic matter allows a significant reduction in the quantity of material to be directed to further processing. Also, it may prove suitable for the recovery of biogas from argillite.

3. Salt roasting combustion of argillite allows weaker acid or alkaline reagents to be used for the further leaching of metals from argillite, which is important in economic terms. Moreover, the method may be taken advantage of in the development of the technology for the further processing of argillite.

4. For the recovery of molybdenum, uranium and vanadium a strongly basic anion exchanger AB-17 was used.

5. The effects of the concentrations of metals and $\mathrm{pH}$ of model solutions on the sorption capacity of anion exchanger AB-17 were studied in two $\mathrm{pH}$ ranges: $1.0-4.0$ and $1.0-2.0$. The factorial main-effect plan was used to estimate the effects.

6. For the selective recovery of uranium and molybdenum the selective elution was used.

7. The recovery of vanadium from acid leachates in significant excess of iron ions by the anion exchange process was ineffective. Therefore, a method for the precipitation of vanadium with iron and the subsequent alkaline leaching with its separation by the anion exchange process were proposed.

8. On the basis of the experiments a general flowsheet for the process of recovery of molybdenum, uranium and vanadium from the argillite leaching solution was presented. 


\section{Acknowledgement}

This work was supported by the Estonian Science Foundation.

\section{REFERENCES}

1. Puura, V. (ed). Geology and Mineral Resources of the Rakvere Phosphoritebearing Area. Institute of Geology of the Estonian SSR Academy of Sciences, Geological Survey of the Estonian SSR, Valgus Publishers, Tallinn, 1987. P. 211 (in Russian).

2. Hade, S., Soesoo, A. Estonian graptolite argillites revisited: a future resource? Oil Shale, 2014, 31(1), 4-18.

3. Lippmaa, E., Maremäe, E., Pihlak, A.-T., Aguraiuja, R. Estonian graptolitic argillites - ancient ores or future fuels? Oil Shale, 2009, 26(4), 530-539.

4. Maremäe, E., Ründal, L., Ahelik, V. Study of the process of multistage leaching of alum shale's sulphated ashes. Oil Shale, 1991, 8(1), 27-38 (in Russian, Summary in English).

5. Maremäe, E., Johannes, I., Ahelik, V. The percolative leaching of alum shale's sulphated ashes. Oil Shale, 1991, 8(2), 138-147 (in Russian, Summary in English).

6. Palvadre, R., Ahelik, V. The distribution of some rare metals in the process of separation of organic matter from Estonian Dictyonema argillite. Oil Shale, 1993, 10(4), 271-281.

7. Pelekis, L., Pelekis, Z., Taure, I., Kirret, O., Rajavee, E. Instrumental neutron activation analysis of alum shale from the Maardu deposit. Proceedings of the Academy of Sciences of the Estonian SSR. Chemistry, 1985, 34(3), 161-164 (in Russian).

8. Pelekis, L., Kirret, O., Taure, I., Pelekis, Z., Eglit, G., Rajavee, E., Ahelik, V. Instrumental neutron activation analysis of Estonian alum shale and some other oil shales. Proceedings of the Academy of Sciences of the Estonian SSR. Chemistry, 1988, 37(1), 1-5.

9. Palvadre, R., Ahelik, V. Possibilities of enhancing the efficiency of using organic-poor oil shales. 1. Oil Shale, 1992, 9(2), 145-149 (in Russian, Summary in English).

10. Palvadre, R., Ahelik, V. On the possibilities of utilizing organic-poor oil shales. 2. Oil Shale, 1992, 9(4), 325-329.

11. Palvadre, R., Loog, A., Haldna, Ü., Ahelik, V., Talkop, R. Correlations between components in Estonian graptolitic argillites. Oil Shale, 1984, 1(3), 292-300 (in Russian).

12. Palvadre, R., Utsal, K., Ahelik, V., Haldna, Ü. Investigation of the mineral composition of Estonian graptolitic argillite. Oil Shale, 1984, 1(2), 162-170 (in Russian).

13. Armands, G. Geochemical studies of uranium, molybdenum, and vanadium 
in a Swedish alum shale. Stockholm Contributions in Geology, University of Stockholm, 1972, 27, 1-148.

14. Leventhal, J. S., Hosterman, J. W. Chemical and mineralogical analysis of Devonian black shale samples from Martin County, KY, Carroll and Washington Counties, OH, Wise County, VA and Overton County, TN, U.S.A. Chemical Geology, 1982, 37, 239-264.

15. Martins, A. Historical overview of using fluidized-bed technology for oil shale combustion in Estonia. Oil Shale, 2012, 29(1), 85-99.

16. Maremäe, E. J., Kirret, O. G. Effect of sulphuric acid on alum shale ashes by a high liquid phase content. Oil Shale, 1989, 6(4), 354-361 (in Russian).

17. Kholmogorov, A. G., Kononova, O. N., Pashkov, G. L., Kachin, S. V., Panchenko, O. N., Kalyakina, O. P. Molybdenum recovery from mineral raw materials by hydrometallurgical methods. The European Journal of Mineral Processing and Environmental Protection, 2002, 2(2), 82-93.

18. Laskorin, B. N., Maurina, A. G., Sviridova, R. A. Recovery of molybdenum and vanadium from sulphate solutions by using solid and liquid anionites. In: Col. Ion Exchange Sorbents in Industry, Moscow, 1963, 124-131 (in Russian).

19. Petersen, I. Experiment planning. Valgus, Tallinn, 1966 (in Estonian).

20. Addelman, S. Orthogonal main-effect plans for asymmetrical factorial experiments. Technometrics, 1962, 4(1), 21-46.

21. Addelman, S. Symmetrical and asymmetrical fractional factorial plans. Technometrics, 1962, 4(1), 47-58.

22. Ruzinov, L. P. Statistical Methods for Optimization of Chemical Processes. Khimiya, Moscow, 1972 (in Russian).

23. Addelman, S. Augmenting factorial plans to accommodate additional two-level factors. Biometrics, 1962, 18(3), 308-322.

Presented by E. Reinsalu

Received January 15, 2020 